Draft paper for the EUSA Fourteenth Biennial Conference, Boston, 5-7 March 2015 - please do not quote without the author's permission

\title{
The Contestation of Values in the European Neighbourhood Policy: Challenges of Capacity, Consistency and Competition
}

\author{
Sieglinde Gstöhl, College of Europe, Bruges, Belgium \\ sieglinde.gstoehl@coleurope.eu
}

\section{Introduction: an expanding community of values?}

When launching the European Neighbourhood Policy (ENP), the European Union (EU) expected that through a steady process of rapprochement, the neighbouring countries would progressively become part of the EU's community of values. The European Commission (2004: 5) declared that "[t]he European Neighbourhood Policy's vision involves a ring of countries, sharing the EU's fundamental values and objectives, drawn into an increasingly close relationship, going beyond co-operation to involve a significant measure of economic and political integration". This promise raised high expectations for a comprehensive regulatory and legislative alignment of the neighbours with significant socio-economic and political reforms according to the priorities set out in jointly agreed Action Plans and with benchmarks that can be monitored and assessed. The Action Plans would cover "first, commitments to specific actions which confirm or reinforce adherence to shared values and [...] secondly, commitments to actions which will bring partner countries closer to the EU in a number of priority fields" (ibid.: 9).

Ten years later, it has become clear that the ambitious goal of expanding the 'zone of prosperity, stability and security' beyond the EU's borders is far - perhaps even further away - from being achieved. The EU's neighbourhood has become politically more fragmented and unstable, the pace of economic and democratic transitions has slowed down, and the EU reluctantly finds itself in competition with Russia over the common eastern neighbourhood while its engagement in the south has been questioned by the Arab uprisings and their unintended consequences. In other words, "there is hardly any other external policy of the EU with a larger gap between its stated objectives and the actual outcome" (Lehne 2014: 4). This paper addresses this puzzle by looking into the promotion of values since values were attributed a prominent role in the ENP.

The EU has since the early 1990s - since the end of the Cold War and since the completion of its internal market - increasingly pursued normative foreign policy objectives and explicitly committed itself to the externalization of both political and economic norms. The political momentum after the fall of Communism had brought about the perspective of democratization and market liberalization worldwide. The EU's aspiration to project these values beyond its borders has further been reinforced by the Treaty of Lisbon. According to Art. 2 TEU, "[t]he Union is founded on the values of respect for human dignity, freedom, democracy, equality, the rule of law and respect for human rights, including the rights of persons belonging to 
minorities". Any European state which respects these values and is committed to promoting them may apply to become a member of the Union (Art. 49 TEU); and the EU shall uphold and promote these values in its relations with the wider world (Art. 3(5) TEU). In addition to human rights and democratic standards, the European Union frequently cites the principles of market economy and sustainable development among the values that it intends to share with its neighbours. These political and economic values are thus constitutive of the EU's self-perception and self-projection abroad.

Manners' (2002: 242) seminal concept of 'normative power Europe' conceives of the EU as a value-driven foreign policy actor based on the core norms that form its own identity (peace, liberty, democracy, rule of law, and respect for human rights and fundamental freedoms). Among the 'minor' norms are social solidarity, antidiscrimination, sustainable development and good governance. Manners (2002: 236, 253) defines 'normative power' as 'the ability to define what passes for 'normal' in world politics", and the most important factor shaping the EU's international role "is not what it does or what it says, but what it is" (ibid.: 252).

In response to the 'normative power Europe' debate, which has mostly focused on political values, Damro (2012: 682) argues that because the European Union is, at its core, a market, it may also be conceptualized as a 'market power Europe' which "exercises its power through the externalization of economic and social marketrelated policies and regulatory measures". He sees the internal market as an alternative basis of the EU's identity, and thus its power, with three interrelated characteristics predisposing the Union to act as a market power: the large size of its market, its institutional features as a regulatory entity and the interest group contestation that this generates (ibid.: 686). Indeed, also the European Commission (2007: 5) perceives the internal market as "a powerful engine to promote EU high quality rules and values around the world" because "[t]hrough the enlargement process and the European Neighbourhood Policy, the Community rulebook is gradually being adopted across large parts of the European continent", and the internal market is "increasingly serving as a reference point in third countries as well as in global and regional fora".

Values underpin more concrete norms and guide action in a given situation. Cremona (2011: 275) argues that "in order to lead to concrete outcomes, the 'values' which have a symbolic significance for the EU must find practical expression in legal norms", whether these norms are derived from the Treaties or imported into the EU's legal order. However, norms may not only be of a legal nature but also comprise social norms about appropriate behaviour and they may have both regulative and constitutive functions. With Björkdahl (2002: 21), norms can be more broadly defined as "intersubjective understandings that constitute actors' interests and identities, and create expectations as well as prescribe what appropriate behaviour ought to be".

In the framework of the European Neighbourhood Policy, the common values are located "principally within the fields of the rule of law, good governance, the respect for human rights, including minority rights, the promotion of good neighbourly relations, and the principles of market economy and sustainable development" (European Commission 2004: 3). The Lisbon Treaty took this policy up and asked the EU to "develop a special relationship with neighbouring countries, aiming to 
establish an area of prosperity and good neighbourliness, founded on the values of the Union and characterised by close and peaceful relations based on cooperation" (Art. 8(1) TEU).

At the outset of the European Neighbourhood Policy, the EU has to a large extent taken these values and their export for granted. This paper asks why the promotion of values in the ENP has become a matter of contestation. It argues that, first, the values themselves have been challenged because of (1) their ambiguous nature, (2) the potential conflicts between them (in particular between political and economic values) resulting in policy incoherence, and (3) the (re-)emergence of competing values in the Arab world and in the post-Soviet space. Second, the mechanisms of value export have been challenged because (1) some neighbours have been incapable and/or unwilling to absorb the values, (2) the EU and its member states have failed to conduct a consistent, credible policy, and (3) the EU is facing normative rivalry from other actors such as Russia in the east. In other words, the European Neighbourhood Policy faces challenges of capacity, consistency and competition.

Following this line of reasoning, the paper is structured in two main parts, the first focusing on issues linked to the values themselves and the second part dealing with the mechanisms of exporting the values, followed by the conclusions.

\section{Contestation of values}

The values in the ENP have been queried for three main reasons: the manifold ambiguities of the nature and substance of values, the shift of focus from political to economic values in the ENP, especially with the advent of Deep and Comprehensive Free Trade Areas (DCFTAs), and the (re-)emergence of competing values in the neighbourhood.

\section{The ambiguity of values}

At least three ambiguities can be discerned besides the fact that the Treaties tend to conflate different concepts into an overlapping terminology of values, principles and objectives (Cremona 2011: 278).

First, the EU on the one hand actively promotes its values in the neighbourhood through various instruments, including conditionality, while on the other hand it appears to assume that these values are already shared and form the basis for developing relations. Art. 21(1) TEU requires the Union to seek to build partnerships with third countries "which share the principles on which it is founded". In particular the neighbouring countries are thereby associated with shared values, as many EU statements on the Stabilization and Association Process with the Western Balkans and on the ENP show (Cremona 2011: 301-303).

A second ambiguity is pointed out by Leino and Petrov (2009) who argue that the EU institutions use the notion of 'common values' as both a universal concept and as an EU concept: on the one hand, the values constitute the EU's foundation, while on the other hand, they are universal. When promoting the values abroad, the Union can thus claim not to be imposing its own values on others but rather using its influence 
to bring the practice of foreign governments in line with their own professed values. The EU also explicitly encourages ENP countries to embrace international norms, for instance by signing up to international agreements. The abstraction of values results in a European Neighbourhood Policy which "formally promotes jointly shared values but which, in practice, amounts to the EU's own reading of them" (ibid.: 656). Hence, views may differ not only with regard to the identification of the relevant values as such but also about their definition, for instance what kind of democracy, market economy or conception of human rights should be promoted. Even within the European Union the member states interpret the 'shared values' not always in the same way. Interestingly, the very first 'Wider Europe' Communication of the European Commission (2003: 3-4) referred to shared values with a footnote to the Charter of Fundamental Rights of the EU, whereas the ENP Strategy Paper one year later focused on international standards, including human rights conventions of the United Nations, the Council of Europe and the Organization for Cooperation and Security in Europe (European Commission 2004: 12-13).

Third, the question arises how the rather abstract values should be implemented. They need to be transposed into concrete reform steps in the Action Plans that can be monitored and, if necessary, enforced. Ghazaryan (2014: 136, 148), for example, finds with regard to democracy promotion in the Southern Caucasus that the ENP Action Plans fall short of translating the political rhetoric on democratic reforms into operational and measureable plans of action and that democratic values are in fact only partially and to varying degrees included. Moreover, the monitoring process and the assistance provided for the implementation of the Action Plans "renders the democratic reform subsidiary, or in some cases irrelevant, within the ENP" (ibid.: 175). More generally, Bosse (2007) argues that there is no coherent discourse on values nor an agreement among EU actors or among and within ENP partners on the contents and significance of these values. Furthermore, there is a gap between the political rhetoric on shared values and the capability to enforce these values. In a similar vein, Kochenov (2014: 53) contends that more attention needs to be paid to the export of values because "the acquis is not necessarily about the values on which the Union is founded", nor can the acquis "be taken as guarantor of such values' enforcement and promotion". In the EU's perspective, the acceptance of values includes the legislative approximation to the often technical, legal acquis. While conditionality may promote the export of acquis, it may be less suitable for the export of values which actors need to internalize.

In addition to the ambiguous nature of values, their substance and coherence has also been questioned.

\section{Conflict potential of values}

In the literature and policy debate the focus has largely been on political values rather than on economic values. Yet, the EU Charter of Fundamental Rights covers both civil and political rights as well as social and economic rights, and the Union's aim to promote "the well-being of its peoples" (Art. 3(1) TEU) includes the establishment of an internal market, sustainable development and "a highly competitive social market economy" (Art. 3(3) TEU). Moreover, solidarity is an express goal of EU external action (Art. 21(1) TEU). 
On the eve of Eastern enlargement, the European Council (2002: para 22) had stated that the dynamics of the accession process presented "an important opportunity to take forward relations with neighbouring countries based on shared political and economic values". The economic reform agenda normally includes accession to the World Trade Organization (WTO) as a prerequisite for concluding a free trade agreement with the EU. The development of the ENP soon embraced 'deep integration' as well as 'deep democracy'. Deep economic integration - as exemplified by the DCFTAs - refers to 'behind-the-border integration' such as common standards or competition rules, in contrast to 'shallow integration' which focuses on the removal of barriers at the border like tariffs and quotas (Lawrence 1996: xviii, 17). In the context of EU external relations, deep economic integration implies legal approximation to or adoption of parts of the EU's acquis. The 2011 review of the ENP introduced the notion of 'deep democracy' which inter alia includes free and fair elections, freedom of association and expression, the rule of law, the fight against corruption, security and law enforcement sector reform and the establishment of democratic control over armed and security forces (European Commission and High Representative 2011: 3). The new Association Agreements with DCFTAs contain a 'common values conditionality' that goes beyond human rights and democratic principles and embraces, for instance, the respect for sovereignty and territorial integrity or the fight against corruption, organized crime, terrorism and proliferation of weapons as well as the principles of free market economy or the promotion of sustainable development and effective multilateralism (Van der Loo, Van Elsuwege and Petrov 2014: 12). However, the latter economic norms are not part of the 'essential elements clause' and cannot trigger a suspension of the agreement in case of a breach.

Nevertheless, economic and political values can be at odds - and the economic concerns often prevail. For example, the pursuit of economic interests and of democratization or political stability may enter into conflict. As pointed out by Panebianco (2006: 141), "economic liberalization and the establishment of free markets - which are also crucial EU values - seem to come before human rights and democratic principles". The Union faces the general problem of how to prioritize among competing ENP goals such as security, good governance and economic aspirations. Art. 21 TEU does not provide a ranking of objectives but simply calls for consistency between the different areas of EU external action and between these and its other policies. Consistency implies, for example, that the EU treats countries in comparable human rights situation in a similar way in terms of sanctions. Consistency is crucial for the EU's credibility, as is the own example set by Europe. Taking a principled stance on human rights and democracy, but then backtracking on it in function of the economic or political importance of the third country concerned, risks damaging the EU's credibility. Overall, the EU has tended to prioritize the first generation of human rights, civil and political rights, over the second generation of economic, social and cultural rights in its external relations (e.g. Kerremans and Orbie 2009: 638; Orbie and Babarinde 467; Bartels 2004: 386; Byrne 2004). Moreover, the EU is said to have a longstanding, marked preference for positive over negative measures in its external relations, with suspension being only a measure of last resort.

Conflicts may also arise within the same group of values, for instance between sustainable development and poverty reduction on the one hand and trade 
liberalization on the other, or between political stability and democratization (Börzel and van Hüllen 2014). EU-sceptical Islamist parties winning free elections in southern ENP countries are a case in point. Although the EU viewed the Arab Spring as a window of opportunity for democracy, as events unfolded, it still prioritized security concerns as a response to the threat of instability in North Africa (Dandashly 2015).

Promoting regional economic integration in the neighbourhood could also be seen as a value, as stated by the European Commission (2004: 4): "The European Neighbourhood Policy will reinforce existing forms of regional and subregional cooperation and provide a framework for their further development." However, so far, the economic relations between the $\mathrm{EU}$ and its partners, reinforced by the principles of differentiation and conditionality, resulted rather in a bilateral 'hub-and-spoke' pattern which militates against regional cooperation (Gstöhl 2012: 100). This is also pointed out by Pace (2007: 662):

"The ideal of 'shared' and 'common' values is [...] reflected in the kind of Europe that is projected to the south: a model of cooperation and peace that should be emulated in the Mediterranean. Yet, the ENP is highly focused on bilateral (rather than multilateral, cooperative and intra-regional) relations."

Finally, although the EU likes to refer to universal values, its policy has been criticized as being Eurocentric or confined to 'Western values'.

\section{The (re-)emergence of competing values}

In order to be a normative power, the outside world has to attribute such a distinct role to an actor. In the post-Western world the EU is but one among several regional actors promoting its norms. The outside perception of the EU as an international economic power is predominant, while it is seen as a weaker political and diplomatic actor (Larsen 2014: 902). More specifically, studies found that "the EU is not viewed as a normative power in Brazil, China, India, Russia and South Africa", nor in the United States, but in its eastern and southern neighbourhood the EU is to some extent perceived as a normative power and values such as human rights and democracy are associated with Brussels (ibid.: 903-904). Nevertheless, the rise of the BRICs and other emerging economies has turned the international system into a multipolar order in which the EU is but one major actor among others. Instead of the 'end of history' - a universalization of Western liberal democracy - alternative models and values have persisted or (re-)surfaced.

Since the end of the Cold War that triggered a wave of democratization and the triumph of the market economy, the European Union has worked on the assumption that its neighbourhood is likely to subscribe to common values. However, while the post-modern European states have been further pooling their sovereignty, many of the 16 ENP partners have been struggling with authoritarian regimes or 'managed democracies'. Whereas Europe has become more secular, political Islam has been on the rise in Turkey and the Arab world. To varying degrees, and with the exception of Azerbaijan and Lebanon, predominantly Muslim societies in ENP countries appear to favour the application of Islamic law (sharia) or at least parts thereof, and a role for religious leaders in politics (Pew Research Center 2013). 
In the post-Soviet space, many policymakers have remained attached to traditional concepts such as national sovereignty and non-interference or zero-sum game spheres of influence. As argued by Korosteleva (2012: 49), the normative disjunction between the West and the former Soviet Union is "deeply rooted in public perceptions whereby people clearly and uncompromisingly differentiate between Western values - of market economy, human rights, democracy and lawfulness and their own values - of peace, tolerance, respect for cultural heritage and religion". Many post-Soviet countries also demonstrate an enduring proclivity for strong leadership and a strong corporate state. In particular the Russian elite considered the Western understanding of human rights "as a dubious concept, insofar as it extends beyond the protection of personal freedom to impose and promote other values that contradict the traditional Russian religious and national values" (Leino and Petrov 2009: 668). Orthodoxy and Russian culture and language are emphasized as key elements of a Russian civilization (Shlapentokh 2013). Kratochvíl (2008: 417) finds that the Russian foreign policy elite believes in state-centrism, in Russia's great power status and that Russia has frequently been treated unfairly. "The deeply ingrained normative underpinnings of Russian foreign policy remain largely incompatible with those of the EU" (ibid.: 398).

\section{Contestation of the promotion of values}

For Manners (2002: 244-245), EU norm diffusion takes place through unintentional diffusion (contagion), informational diffusion (strategic and declaratory communications), procedural diffusion (in an institutionalized relationship), transference (for instance through trade and aid) or overt diffusion (through physical EU presence). If the export of values is understood - as is the case in the ENP - as a deliberate and active attempt of the Union to externalize norms rather than just an essentially passive influence, the main mechanisms are linked to procedural and transference diffusion. In a similar vein, Damro (2012: 692) argues that the EU exercises its market power through tools "such as the use of positive and negative conditionality, international legal instruments and internal regulatory measures" in its relations to both states and non-state actors. The 'market access conditionality' in the DCFTAs, for instance, is based on a strict monitoring process, inspired by the pre-accession methodology, and the process of legislative approximation and the effective enforcement and implementation of the agreement are subject to permanent scrutiny (Van der Loo, Van Elsuwege and Petrov 2014: 28).

The EU engages in promoting its values and norms through unilateral instruments, bilateral agreements or non-binding instruments such as human rights or policy dialogues, Council conclusions, people-to-people exchanges, Action Plans and Progress Reports (Cremona 2011: 292-307). Ex ante conditionality may require that certain conditions be fulfilled before entering or upgrading a relationship or lifting sanctions under the Common Foreign and Security Policy. Ex post conditionality is present in various EU instruments: the most common are human rights and democracy clauses in bi- or multilateral agreements and in regulations of financial aid (except for humanitarian assistance) or in autonomous trade preferences. Positive conditionality promises benefits to a country for desired action, while negative conditionality threatens punitive sanctions for not respecting crucial norms and values. These incentives and disincentives may also be combined in a "carrot and stick' policy as in the ENP. 
These mechanisms of value export have been challenged. Some neighbours at the receiving end have been unable and/or unwilling to accept and absorb the values, or the EU and its member states have failed to conduct a consistent and credible policy, especially with regard to conditionality, and they had to face the normative rivalry of other external actors.

\section{Lack of capacity and/or willingness in ENP countries}

The European Union enjoys weaker political leverage, the lower the willingness and the capacity of governments and other domestic actors in the ENP countries to deal with reforms (Börzel 2011: 400; Gstöhl 2008: 285-288).

First, a crucial precondition for a successful norm export is the political will in the ENP countries to tackle the domestic reforms required. In authoritarian regimes veto players are most likely placed at the governmental level and an EU norm export will in particular depend on its anticipated effects on the executive's power, that is the political costs of adopting reforms (Schimmelfennig and Sedelmeier 2004: 670). In other words, the EU's challenge "remains how to put pressure on [...] governments to aim for 'common values' (in particular democratic reforms) when these governments view such norms as threatening their own hold on power" (Pace 2007: 663). Moreover, the resonance of EU values is not the same in all societies. Socialization research suggests that persuasion is more likely if the target is in a novel and uncertain environment, has few ingrained beliefs inconsistent with the socializing institution and wants to belong to the latter (Checkel 2005: 813). Transition countries tend to be more receptive to EU norms than authoritarian regimes because they are likely to be more open to new ideas after their old governance systems were discredited.

Second, a lack of absorption capacity may hamper political and economic reforms. For economies lacking strong institutions and administrative capacities, regulatory approximation to EU standards can involve onerous costs, possibly resulting in higher domestic prices and trade diversion (Messerlin et al. 2011: i-ii). It can, for instance, be questioned whether the Deep and Comprehensive Free Trade Areas requiring alignment to and selective adoption of EU acquis are the most suitable instruments for countries facing serious development challenges. The DCFTAs cover substantially all trade in goods and services as well as 'behind-the-border' issues, such as technical and other standards, competition policy, industrial policy, intellectual property rights, company law, public procurement and financial services. By replicating the enlargement process, the ENP causes the EU's neighbours "to lose a level of independence at a crucial time in their democratic reform and economic restructuring programmes" while receiving fewer benefits in return than the applicant countries did (Leino and Petrov 2009: 665).

The Association Agreements with Ukraine, Moldova and Georgia, signed in June 2014, contain several legislative approximation mechanisms with varying degrees of obligation and various procedures to amend the incorporated rules. Also the dispute settlement varies across sectors from consultation, arbitration or mediation to rulings by the Court of Justice of the EU (Van der Loo, Van Elsuwege and Petrov 2014: 1422). In particular, the countries commit to incorporate the relevant acquis regarding 
technical barriers to trade and certain services. The Association Council monitors the application of the agreement and serves as forum to discuss new relevant legislation. As already mentioned, the DCFTAs are based on far-reaching 'market access conditionality' which links additional access to the internal market to the country's progress in implementation. They entail "a move from the soft law approach based on persuasion and assistance to a comprehensive, binding and detailed legal framework structuring relations between the EU and its Eastern neighbours" (Delcour and Wolczuk 2013: 190). Nevertheless, a country's commitment to adopt and implement EU norms does not necessarily mean that this is actually followed up by their transposition into domestic law, nor by their application (Langbein and Wolczuk 2012). The will and the capacity to adapt, as necessary, the political systems, economies and societies to the imported norms remain crucial.

\section{Lack of capacity and/or willingness in the EU}

The value export may be hampered not only by shortcomings in the ENP countries but also by inadequacies on the side of the European Union: the lack of political will, capacity or, as a result, inconsistency.

First, the (un)willingness of the EU actors or the member states to deliver certain incentives can be seen in light of the transposition of the enlargement methodology to the ENP despite the lack of an EU membership perspective. The European Union was not ready to make any accession promises to the Eastern partners and left the ENP's ultimate objective open. In 2006 the European Commission (2006: 5) introduced the concept of "a longer-term vision of an economic community emerging between the EU and its ENP partners", which "would include such points as the application of shared regulatory frameworks and improved market access for goods and services among ENP partners, and some appropriate institutional arrangement such as dispute settlement mechanisms". Such a Neighbourhood Economic Community would offer the neighbours 'a stake' in the internal market (see Gstöhl 2012). This future perspective may not be sufficiently attractive and concrete for some neighbours. The existence of a membership option may not only encourage the partner countries to make a bigger effort but also the EU. Without such a perspective, the EU's ability to deliver real incentives, such as the liberalization of agricultural exports, labour migration or EU involvement in the resolution of regional conflicts, remains constrained since it includes areas in which the Union faces strong vested interests in some EU member states. Some progress has been made over time with regard to trade in agricultural products and visa liberalization. Although the ENP was to "reinforce stability and security and contribute to efforts at conflict resolution" and to promote good neighbourliness (European Commission 2004: 4), in practice the EU has been rather reluctant to get involved in the conflicts in Moldova (Transnistria), Georgia (Abkhazia and South Ossetia), Azerbaijan-Armenia (Nagorno-Karabakh) or the Western Sahara and the Israeli-Palestinian conflict, not to mention the wars in Libya and Syria.

Second, the EU may not only lack the necessary member state support but also the legal competences or face other constraints to act on certain issues. A case in point is the non-participation of the neighbours in the decision-making process about the actual meaning of common values and their further development (Leino and Petrov 
2009: 666-667). This lack of 'input legitimacy' - or real joint ownership - hampers the internalization of norms in ENP countries. As non-EU members, the neighbours risk facing a fundamental dilemma the more closely they become involved with the EU. Other neighbourhood models of deep economic integration, such as the EU-Turkey customs union, the EU-Swiss bilateralism or the European Economic Area, have in recent years reached their limits since they cover more and more sectors but lack efficient institutional arrangements for ensuring the necessary market homogeneity (Gstöhl 2015). The Council of the EU (2012: 5-6) underlined that any close relationships with neighbouring countries must be guided by the principles of homogeneity and legal certainty because they "guarantee the efficiency, sustainability and ultimately the credibility of the single market". This increasingly implies the conclusion of agreements which foresee a dynamic adaptation to the acquis, its uniform interpretation as well as an independent surveillance and judicial enforcement. Such a measure of supranationality without full participation in the relevant EU decision-making processes encroaches upon national autonomy. The DCFTAs provide only for a limited form of 'decision-shaping' in specific areas where full internal market treatment is foreseen (Van der Loo, Van Elsuwege and Petrov 2014: 19).

Third, the lack of capacity and/or willingness to offer the ENP countries certain benefits or to endorse the values by reacting to non-compliance may generate inconsistent EU policies. This may concern either vertical consistency between EU policies and national policies of the member states or horizontal consistency between different EU policies. For example, the EU's promotion of human rights and democracy in the ENP has frequently been trumped by economic or security interests (see Balfour 2006; Ghazaryan 2014: 172-176). The Arab Spring caught Europe off guard and revealed how the EU and its member states had for the sake of political stability (including containing the flows of migration, terrorism and organized crime) connived with authoritarian regimes. The EU's engagement with autocratic regimes in ENP countries has over time become more pragmatic, shifting towards functional cooperation. For Bosse (2012: 367) "[t]his development is potentially serious, as it appears to mark the beginning of the end of the EU's ambition to act as a successful democratizer in its immediate neighbourhood". Kurki (2011: 230-231) argues that the technocratic approach glosses over the unclear normative meaning of democracy in EU discourse and that it pulls EU democracy promotion "towards depoliticisation, assumptions of harmony, rationalistic and economistic methods, objectivist measurements and management, and technocratic rather than democratic ways of legitimising policies". On the other hand, a low-profile approach to democracy promotion may help promote the socialization and internalization of norms in societies and officials. While the EU institutions are entangled in bureaucratic technicalities, the EU member states often ignore conditionality in their bilateral dealings with ENP countries. In order to be effective, however, the member states must be willing to support EU conditionality policy instead of disengaging or even pursuing detrimental policies.

Finally, in addition to domestic factors in either the ENP countries or the EU, the role of external competitors may play a role because of competing mechanisms of value export. The Russia-Georgian war in 2008, the consequences of the Arab Spring since 2010, and in particular the annexation of Crimea in 2014 and the war in eastern Ukraine have served as wake-up calls for the EU to think more geopolitically. 


\section{Normative (market) power rivalry}

The EU's efforts of value promotion are based on the assumption that the (European) model of democracy and market economy can and should be exported. However, this assumption may be questioned not only by the ENP countries themselves but also by external actors. While the east struggles with the 'Russia factor', in the south a number of players ranging from the US to Turkey, Russia, China, Saudi Arabia and Qatar pursue their own agenda (Lehne 2014: 9).

In the Southern Mediterranean several countries, especially Tunisia, Egypt, Libya and Syria, rebelled against Western-backed authoritarian rulers. In some countries powerful counter-revolutions have taken place afterwards. The rich Gulf monarchies have tried to 'buy off' their citizens and supported regressive forces in the region, including in the Maghreb, while the poorer monarchies Morocco and Jordan implemented rather cosmetic domestic reforms (Leonard 2014). Democracy promotion implies that the EU must engage in dialogue with all political groups and not just those that mirror Western values. Political Islam is not a unitary force but characterized by important splits between different interpretations of Islam such as between the Shi'ite and Sunni and between the Muslim Brotherhood and the Salafists. As argued by Leonard (2014), the political awakening in the Arab Spring "is about people claiming democratic rights to emancipate themselves from the traditional influence of the West, rather than trying to join it".

In the East, the European Union shares an overlapping neighbourhood with an increasingly assertive Russia that has reverted to great power aspirations. Russia had from the very beginning opted out of the ENP and insisted on a strategic partnership 'between equals'. In addition, the Russian government began to increasingly put forward its own normative agenda in the region. As argued by Haukkala (2008: 41), energy-rich Russia can use mechanisms that are not at the EU's disposal to foster bilateral relations, it plays a role in many 'frozen conflicts' in the region, and it has sought to develop "an alternative model of economic modernisation and societal development to that promoted by the EU". By offering a different set of national, cultural and religious values for the post-Soviet space, "the language of values also provides Russia with a possibility to challenge the conditionality policy attached to the EU's reading of the values it declares" (Leino and Petrov 2009: 669).

Moreover, the Russian market is broadly accessible to countries that share the legacy of Soviet standards. The GOST technical standards are less competitive than the EU standards, and the implementation of the DCFTAs would imply a gradual phasing out of GOST standards (Dreyer and Popescu 2014: 2). When Russia in 2011 proposed to develop its customs union with Belarus and Kazakhstan into a Eurasian Economic Union that could extend to the post-Soviet space, it de facto compelled countries in the common neighbourhood to choose between this project and a DCFTA with the EU, unless the EU would instead conclude an FTA with the entire Eurasian customs union (Delcour and Kostanyan 2014: 5). Russia presented the Eurasian integration as a project of economic modernization based on international law but did not shy away from threatening sanctions vis-à-vis its neighbours (Delcour and Wolczuk 2013: 192-197). The announcement of the 
Armenian government in the run-up to the Eastern Partnership Summit in Vilnius in November 2013 that it intended to join the Eurasian customs union and the decision of the Ukrainian government to suspend the signature of its Association Agreement and DCFTA with the EU clearly demonstrated that these countries are facing two 'centres of gravity'. The Eurasian integration project "means that the EU is no longer the only actor promoting deep economic integration premised on regulatory convergence in the post-Soviet space" (ibid.: 180). However, the economic benefits of the Eurasian Economic Union launched in 2015 are questionable given the high tariff levels that make imports from the EU and China more expensive and question the commitments of WTO members Armenia and Kyrgyzstan while complicating Kazakhstan's negotiations on WTO accession. Russia therefore offers a range of subsidies to its (potential) partners in the form of cheaper gas or loans and access to its labour market (Popescu 2014: 11-14).

In the end, the ENP's value export proved more attractive for Moldova, Georgia and finally - after the 'EuroMaidan revolution' - to Ukraine than to Armenia, Azerbaijan or Belarus, although the latter share some concerns about Russia's dominance in the Eurasian Economic Union.

\section{Conclusions: conceptual flaws beyond implementation problems}

In the post-Cold War era the EU has increasingly emphasized the role of values in its external action and in particular in its neighbourhood. The Lisbon Treaty made it even clearer that any EU foreign policy strategy should be based upon both values and interests. As the European Neighbourhood Policy unfolded over time, the resistance that the promotion of values encountered in some countries has been growing instead of fading away. This paper examined the role of values in the ENP and the reasons for their unexpected contestation in recent years. It has been argued that the values themselves have been challenged because of their ambiguity, potential conflicts between them and the (re-)emergence of competing values abroad. In addition, the promotion of values has been questioned due to factors linked to the incapacity and/or unwillingness of either the neighbours or of the EU and its member states, and because of the normative rivalry of other external actors. More precisely, the ENP has been plagued by implementation problems such as an inconsistent and selective application of political conditionality, often disengaged EU member states, a techno-bureaucratic approach that turned out to be too demanding for many countries.

In a nutshell, the role of values in the ENP has been facing challenges of capacity, consistency and competition. In addition to such implementation problems, the ENP has suffered from certain conceptual flaws (see also Lehne 2014): first of all, the policy embraces sixteen countries that have little in common except for their geographical proximity to the EU. Originally designed for 'Wider Europe' in the immediate east to the EU, the ENP was quickly extended to the Southern Mediterranean and the Southern Caucasus. The heterogeneity of the countries in these two geographical dimensions led a few years later to the creation of the Union for the Mediterranean and the Eastern Partnership.

Second, the ENP has produced a 'hub-and-spoke' system of bilateral relationships at the expense of a regional approach, as illustrated by the patterns of trade and 
investment flows (Kallioras 2013). The EU's initiatives to promote regional cooperation in its neighbourhood have also been hampered by the contested nature of the regions and confusion over the goals of regional cooperation, the gap between the ends sought by the EU and the means available to it, and the existence of enduring conflicts in these regions (Cottey 2012).

Third, the ENP applies a methodology that has largely been derived from the enlargement process, such as targeted expert assistance, twinning arrangements with member state administrations, participation in EU programmes and agencies, conditionality policy, monitoring and progress reports, as well as the bilateral rather than multilateral focus. Moreover, the EU's assumption that all partner countries were trying to emulate the European model was mistaken. The long-term perspective of a Neighbourhood Economic Community may, however, not make up for the lack of an accession perspective as a motivation for reforms and approximation. The ENP has largely been driven by the European Commission, later joined by the newly created European External Action Service, but the member states have often remained disengaged or pursued their own bilateral foreign policy vis-à-vis the ENP countries. In this context, the lack of participation of the ENP countries in the decision-making - or at least decision-shaping - process sits in the long run squarely with the principle of joint ownership and an expanding 'stake' in the internal market.

Fourth, the ENP's principle of joint ownership appears somewhat at odds with the principle of political conditionality which states that "the level of ambition of the EU's relationships with its neighbours will take into account the extent to which these values are effectively shared" (European Commission 2004: 3), resulting in a policy of differentiation among the ENP partners. The 2011 review of the ENP introduced an even more explicit 'more for more' approach: "only those partners willing to embark on political reforms and to respect the shared universal values of human rights, democracy and the rule of law have been offered the most rewarding aspects of the EU policy, notably economic integration [...], mobility of people [...], as well as greater EU financial assistance" (European Commission and High Representative 2012: 3-4). Moreover, joint ownership allows ENP countries to downgrade the role of values in Action Plans to which they are opposed.

Fifth, a Eurocentric approach to the ENP tends to ignore the role of other influential actors in the neighbourhood. These other actors may pursue different and competing objectives. The EU was not prepared for the challenges that its - supposedly universal - values and their promotion have met. It did not sufficiently think strategically ahead. Adding a more geopolitical approach may help sharpen the EU's strategic focus and make it a more influential international partner. The Union and its member states need to rely on clear values, interests and matching capabilities and avoid incoherent policies in order to credibly address the growing expectations regarding the export of stability, peace and prosperity. The EU needs to strike a better balance between the promotion of values and geostrategic thinking - which does not imply a zero-sum game vision. The ENP review that European Commission is planning to carry out in 2015 offers an opportunity to reconsider this approach. 


\section{Bibliography}

Balfour, Rosa (2006), "Principles of Democracy and Human Rights: A Review of the European Union's Strategies towards its Neighbours", in Sonia Lucarelli and Ian Manners (eds.), Values and Principles in European Union Foreign Policy, London, Routledge, 114-129.

Bartels, Lorand (2004), "Legal Analysis of Human Rights Clauses in the European Union's EuroMediterranean Association Agreements", Mediterranean Politics, 9(3), 368-395.

Björkdahl, Annika (2002), "Norms in International Relations: Some Theoretical and Methodological Reflections", Cambridge Review of International Affairs, 15(1), 9-23.

Börzel, Tanja A. (2011), "When Europe Hits ... beyond Its Borders: Europeanization and the Near Abroad", Comparative European Politics, 9(4-5), 2011, 394-413.

Börzel, Tanja A. and Vera van Hüllen (2014), "One Voice, One Message, but Conflicting Goals: Cohesiveness and Consistency in the European Neighbourhood Policy", Journal of European Public Policy, 21(7), 1033-1049.

Bosse, Giselle (2012), "A Partnership with Dictatorship: Explaining the Paradigm Shift in European Union Policy towards Belarus", Journal of Common Market Studies, 50(3), 367-384.

Bosse, Giselle (2007), "Values in the EU's Neighbourhood Policy: Political Rhetoric or Reflection of a Coherent Policy?", European Political Economy Review, 7, 38-62.

Byrne, Iain (2004), "The Importance of Economic, Social and Cultural Rights in Guaranteeing Civil and Political Rights with the Euro-Mediterranean Partnership", Mediterranean Politics, 9(3), 344-367.

Checkel, Jeffrey T. (2005), "International Institutions and Socialization in Europe: Introduction and Framework", International Organization, 59(4), 801-826.

Cottey, Andrew (2012), "Regionalism and the EU's Neighbourhood Policy: The Limits of the Possible", Journal of Southeast European and Black Sea Studies, 12(3), 375-391.

Council of the EU (2012), "Council conclusions on EU relations with EFTA countries", 3213th Transport, Telecommunications and Energy Council meeting, Brussels, 20 December.

Cremona, Marise (2011), "Values in EU Foreign Policy", in Malcolm Evans and Panos Koutrakos (eds.), Beyond the Established Orders: Policy Interconnections between the EU and the Rest of the World, Oxford, Hart Publishing, 275-315.

Damro, Chad (2012), "Market Power Europe", Journal of European Public Policy, 19(5), 682-699.

Dandashly, Assem (2015), "The EU Response to Regime Change in the Wake of the Arab Rrevolt: Differential Implementation", Journal of European Integration, 37(1), 37-56.

Delcour, Laure and Hrant Kostanyan (2014), "Towards a Fragmented Neighbourhood: Policies of the EU and Russia and their consequences for the area that lies in between", CEPS Essay, no. 17, Brussels, 17 October.

Delcour, Laure and Kataryna Wolczuk (2013), "Eurasian Economic Integration and Implications for the EU's policy in the Eastern Neigbhourhood", in Dragneva, Rilka \& Kataryna Wolczuk (eds.), Eurasian Economic Integration: Law, Policy, and Politics, Cheltenham: Edward Elgar, 179-203.

Dreyer, Iana and Nicu Popescu (2014), "Trading with Moscow: the law, the politics and the economics", Brief, no. 31, Paris, EUISS.

European Commission and High Representative (2012), Joint Communication to the European Parliament, the Council, the European Economic and Social Committee and the Committee of the Regions, "Delivering on a new European Neighbourhood Policy", JOIN(2012) 14, Brussels, 15 May. 
European Commission and High Representative (2011), Joint Communication to the European Parliament, the Council, the European Economic and Social Committee and the Committee of the Regions, "A New Response to the Changing Neighbourhood", COM(2011) 303, Brussels, 25 May.

European Commission (2007), Commission Staff Working Document, The External Dimension of the Single Market Review, SEC(2007) 1519, Brussels, 20 November.

European Commission (2006), Communication from the Commission to the Council and the European Parliament on Strengthening the European Neighbourhood Policy, COM(2006) 726 final, Brussels, 4 December.

European Commission (2004), Communication from the Commission, European Neighbourhood Policy - Strategy Paper, COM(2004) 373, 12 May.

European Commission (2003), Communication from the Commission to the Council and the European Parliament, Wider Europe - Neighbourhood: A New Framework for Relations with our Eastern and Southern Neighbours, COM(2003) 104, 11 March.

European Council (2002), Presidency Conclusions, Copenhagen, 12-13 December.

Ghazaryan, Nariné (2014), The European Neighbourhood Policy and the Democratic Values of the EU: A Legal Analysis, Oxford, Hart Publishing.

Gstöhl, Sieglinde (2015), "Models of External Differentiation in the EU's Neighbourhood: An Expanding Economic Community?", Journal of European Public Policy, 22(5), forthcoming.

Gstöhl, Sieglinde (2012), "What is at Stake in the Internal Market? Towards a Neighbourhood Economic Community", in Erwan Lannon (ed.), The European Neighbourhood Policy's Challenges / Les défis de la politique européenne de voisinage, Brussels, P.I.E. Peter Lang, 85-108.

Gstöhl, Sieglinde (2008), "The EU as a Norm Exporter?", in Dieter Mahncke and Sieglinde Gstöhl (eds.), Europe's Near Abroad: Promises and Prospects of the EU's Neighbourhood Policy, Brussels, P.I.E. Peter Lang, 279-293.

Haukkala, Hiski (2008), "The Russian Challenge to EU Normative Power: The Case of European Neighbourhood Policy", International Spectator, 43(2), 35-47.

Kallioras, Dimitris (2013), "Trade activity between the EU and the ENP countries: A 'reproduction' of the 'core-periphery' pattern?", SEARCH Working Paper 2/06, September, http://www.ub.edu/searchproject/wp-content/uploads/2013/09/SEARCH_Working-Paper_2.06.pdf (accessed October 2014).

Kerremans, Bart and Jan Orbie (2009), "The Social Dimension of European Trade Policies", European Foreign Affairs Review, 14(5), 629-641.

Kochenov, Dimitry (2014), "The Issue of Values", in Peter Van Elsuwege and Roman Petrov (eds.), Legislative Approximation and Application of EU Law in the Eastern Neighbourhood of the European Union: Towards a Common Regulatory Space?, London, Routledge, 46-62.

Korosteleva, Elena (2012), "Questioning Democracy Promotion: Belarus' response to the 'colour revolutions", Democratization, 19(1), 37-59.

Kratochvíl, Petr (2008), "The Discursive Resistance to EU-Enticement: The Russian Elite and (the Lack of) Europeanisation", Europe-Asia Studies, 60(3), 397-422.

Langbein, Julia and Kataryna Wolczuk (2012), "Convergence without Membership? The Impact of the European Union in the Neighbourhood: Evidence from Ukraine", Journal of European Public Policy, 19(6), 863-881. 
Larsen, Henrik (2014), "The EU as a Normative Power and the Research on External Perceptions: The Missing Link", Journal of Common Market Studies, 52(4), 896-910.

Lavenex, Sandra (2014), "The Power of Functionalist Extension: How EU Rules Travel", Journal of European Public Policy, 21(6), 885-903.

Lawrence, Robert Z. (1996) Regionalism, Multilateralism, and Deeper Integration, Washington, D.C.: The Brookings Institutions.

Lehne, Stefan (2014), "Time to Reset the European Neighbourhood Policy", Brussels, Carnegie Europe, February.

Leino, Päivi and Roman Petrov (2009), "Between 'Common Values' and Competing Universals - The Promotion of the EU's Common Values through the European Neighbourhood Policy", European Law Journal, 15(5), 654-671.

Leonard, Mark (2014), "Seven reasons why the Arab uprisings are eclipsing Western values", European Council on Foreign Relations, 23 January.

Manners, Ian (2002), "Normative Power Europe: A Contradiction in Terms?", Journal of Common Market Studies, 40(2), 235-258.

Messerlin, Patrick, Michael Emerson, Gia Jandieri and Alexandre Le Vernoy (2011), An Appraisal of the EU's Trade Policy towards its Eastern Neighbours: The Case of Georgia, Brussels, CEPS, and Paris, Sciences Po.

Orbie, Jan and Olufemi Babarinde (2008), "The Social Dimension of Globalization and EU Development Policy: Promoting Labour Standards and Corporate Social Responsibility", Journal of European Integration, 30(3), 459-477.

Pace, Michelle (2007), "Norm Shifting from EMP to ENP: the EU as a Norm Entrepreneur in the South?", Cambridge Review of International Affairs, 20(4), 659-675.

Panebianco, Stefania (2006), "The Constraints on EU Action as a 'Norm Exporter' in the Mediterranean", in Ole Elgström and Michael Smith (eds.), The European Union's Roles in International Politics: Concepts and Analysis, London, Routledge, 136-154.

Pew Research Center (2013), The World's Muslims: Religion, Politics and Society, Washington, D.C., 30 April.

Popescu, Nico (2014), "Eurasian Union: The Real, the Imaginary and the Likely", Chaillot Papers, no. 132, Paris, European Union Institute for Security Studies.

Schimmelfennig, Frank and Ulrich Sedelmeier (2004), "Governance by Conditionality: EU Rule Transfer to the Candidate Countries of Central and Eastern Europe", Journal of European Public Policy, 11(4), 661-679.

Shlapentokh, Dmitry (2013), "The Death of the Byzantine Empire and Construction of Historical/Political Identities in Late Putin Russia", Journal of Balkan and Near Eastern Studies, 15(1), 69-96.

Van der Loo, Guillaume, Peter Van Elsuwege and Roman Petrov (2014), "The EU-Ukraine Association Agreement: Assessment of an Innovative Legal Instrument", EUI Working Papers, LAW 2014/09, Florence, European University Institute. 